\title{
IMPLEMENTASI SISTEM E-COMMERCE PADA GUNA MOTOR BERBASIS CONTENT MANAGEMENT SYSTEM (CMS) WORDPRESS
}

\author{
Febrianto Azis Irfannudin ${ }^{1)}$, Agus Umar Hamdani ${ }^{2)}$ \\ ${ }^{1}$ Sistem Informasi, Fakultas Teknologi Informasi, Universitas Budi Luhur \\ 1,2Jl. Raya Ciledug, Petukangan Utara, Kebayoran Lama, Jakarta Selatan 12260 \\ E-mail : febrianto.azis01@gmail.com ${ }^{1)}$, agus.umarhamdani@budiluhur.ac.id ${ }^{2)}$
}

\begin{abstract}
Abstrak
Guna Motor adalah badan usaha perorangan yang bergerak dibidang jasa penjualan sparepart \& aksesoris mobil didirikan pada tahun 2006. Dimana sistem yang saat ini berjalan pada Guna Motor dalam mengembangkan usahanya memiliki berbagai kendala pada saat proses pengolahan data dalam melakukan transaksi dan melayani customer yang masih belum efektif seperti yang sering terjadi customer sulit mengetahui ketersediaan stok produk, tempat penyimpanan dokumen kurang baik dan tidak adanya pemasaran produk secara luas. Untuk menyelesaikan permasalahan yang ada di Guna Motor, maka penulis melakukan penelitian guna membantu pihak manajemen untuk menyelesaikan masalah yang terjadi dengan merancang sistem ecommerce, dalam pembuatan penelitian ini, penulis mengimplementasikan menggunakan Content management system (CMS) dengan metode pengembangan sistem waterfall dan aplikasi Search Engine Optimization (SEO) yoast seo. Hasil akhir dalam pembuatan penelitian ini berupa aplikasi website e-commerce yang bermanfaat bagi Guna motor dan customer, mampu bertahan dan bersaing dengan penyedia jasa yang serupa serta membantu mengatasi masalah - masalah yang sering terjadi.
\end{abstract}

Kata kunci: E-Commerce, Sparepart, Aksesori Mobil, Content Management System (CMS)

\section{PENDAHULUAN}

Teknologi saat ini memberikan banyak manfaat dalam membantu menyelesaikan masalah dan mulai berkembang hampir kesemua bidang usaha. ECommerce merupakan sebagai sarana terjadinya transaksi atau pertukaran informasi antara penjual dan pembeli didunia maya[1]. Content Management System (CMS) merupakan aplikasi berbasis web yang digunakan untuk mengatur konten pada website. Content Management System (CMS) memiliki kemampuan untuk membuat dan mengupdate artikel, mengedit halaman website, mengatur menu dan tampilan website[2].

Guna Motor adalah badan usaha perorangan bergerak dibidang penjualan spare part \& aksesoris mobil yang masih menggunakan sistem manual dalam pengelolaan data penjualan. Dalam proses melayani customer ada berbagai masalah dalam melakukan transaksi dan transaksi yang menggunakan catatan mengakibatkan proses transaksi yang lain menjadi terhambat.

Dari permasalahan yang ada dibutuhkan sistem informasi untuk membantu pengelolaan data transaksi yang ada menjadi lebih mudah dan cepat seperti membuatkan website situs jual online agar pelanggan melakukan transaksi tidak hanya melalui media catatan melainkan bisa melakukan pemesanan lewat website online. Dalam membangun ECommerce untuk Guna Motor penelitian melakukan peninjauan terhadap peneliti sebelumnya sebagai berikut: "Model E-Commerce Dengan Metode Web Engineering Method Untuk Menunjang Pemasaran
Produk pada XYZ Pet Shop” yang membahas pembuatan prototipe E-Commerce guna menunjang aktivitas penjualan dan pemasaran produk makan hewan peliharaan pada XYZ Pet Shop[3]. Untuk permasalahan yang terjadi pada Guna Motor adalah : pengelolaan data pemesanan kurang baik/kurang efektif, kesulitan mengetahui pemesanan barang, kesulitan mengetahui stok barang, tempat penyimpanan dokumen penjualan kurang baik, dan promosi tidak berjalan dengan baik. Dalam melakukan perumusan masalah yang harus dijawab adalah membuat aplikasi E-Commerce guna memaksimalkan penjulan dan pemasaran pada Guna Motor. Adapun tujuan penelitian yang dilakukan adalah membuat system E-commerce untuk mempermudah pemasaran produk secara online dan mendukung penjualan pada Guna Motor

\section{METODE PENELITIAN}

Berikut gambar 1 merupakan penjelasan mengenai langkah langkah penelitian :

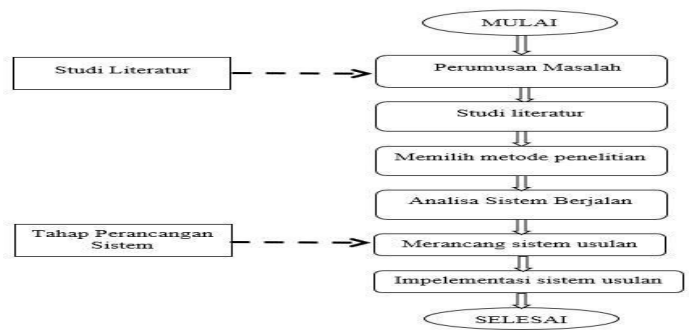

Gambar 1. Langkah-Langkah Penelitian 
Berikut mengenai penjelasan langkah-langkah penelitian diatas:

a Perumusan masalah

Merumuskan masalah yang ada di Guna Motor merupakan hasil dari kegiatan observasi dan wawancara secara langsung dengan para karyawan penjualan barang untuk mendapatkan gambaran jelas tentang keadaan organisasi.

b Studi literatur

Pada studi literatur ini adalah untuk mendaptak teori teori tentang E-Commerce serta teori umum yang terkait dengan rumusan masalah. Metode yang dilakukan peneliti yaitu dengan membaca berbagai referensi dan artikel manapun skripsi yang telah dipublikasikan.

c Memilih Metode Penelitian

Pada tahapan ini peneliti menentukan metode penelitian ini berupa sistem yang menggunakan pendekatan berbasis obyek, bahasa pemograman menggunakan

d Analisa Sistem Berjalan

Dalam analisa sistem berjalan peneliti menggunakan tool Activity Diagram, mendefinisikan permasalahan yang terjadi dan memodelkan permasalahan.

e Merancang Sistem Usulan

Pada tahap ini peneliti melakukan identifikasi kebutuhan sistem yang akan di buat dengan memodelkan sistem usulan menggunakan tools use case diagram serta deskripsi use case, pembuatan struktur menu, rancangan layar, system sequence diagram, class diagram dan mejelaskan basis data menggunakan model data Interaction Flow Modelling Language (IFML).

f Implementasi Sistem Usulan

Peneliti menginplementasikan model sistem usulan menggunakan bahasa pemograman

\section{HASIL DAN PEMBAHASAN}

\subsection{Business Model Canvas}

Berikut ini meruapakan model yang ada didalam BMC (Business Model Canvas) Guna Motor dijelaskan pada gambar 2 sebagai berikut:

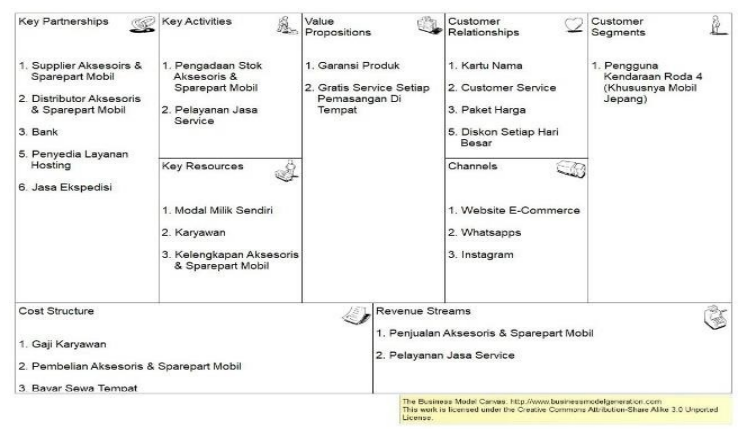

Gambar 2. Langkah - Langkah Penelitian BMC
Berikut penjelasan komponen-komponen yang terdapa pada gambar 2 sebagai berikut :

Tabel 1. Komponen langkah-langkah penelitian BMC

\begin{tabular}{|c|c|}
\hline Komponan BMC & Penjelasan \\
\hline 1. Value Proposition & $\begin{array}{l}\text { - Garansi Produk } \\
\text { - Garansi Service Setiap } \\
\text { Pemasangan Di Tempat }\end{array}$ \\
\hline 2. Customer Segments & 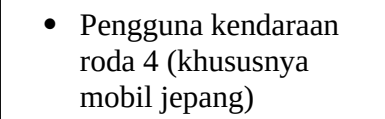 \\
\hline 3. Customer Relationship & $\begin{array}{l}\text { - Kartu nama } \\
\text { - Customer service } \\
\text { - Paket harga } \\
\text { - Garansi service } \\
\text { - Diskon setiap hari besar }\end{array}$ \\
\hline 4. Channels & $\begin{array}{l}\text { - Website e-commerce } \\
\text { - Whatsapps } \\
\text { - Instagram }\end{array}$ \\
\hline 5. Key Partnerships & $\begin{array}{ll}\text { - } & \text { Supplier aksesoris \& } \\
& \text { sparepart mobil } \\
\text { - } & \text { Distributor aksesoris \& } \\
\text { sparepart mobil } \\
\text { - } \text { Bank } \\
\text { - Penyedia layanan } \\
\text { - hosting } \\
\text { - Jasa ekspedisi }\end{array}$ \\
\hline 6. Key Activities & $\begin{array}{l}\text { - Penjualan aksesoris \& } \\
\text { sparepart mobil } \\
\text { - Pelayanan jasa service }\end{array}$ \\
\hline 7. Key Resources & $\begin{array}{l}\text { - Modal milik sendiri } \\
\text { - Karyawan }\end{array}$ \\
\hline 8. Cost Structure & $\begin{array}{l}\text { - Gaji karyawan } \\
\text { - Pembelian aksesoris \& } \\
\text { saprepart mobil } \\
\text { - Biaya sewa tempat } \\
\text { - Biaya hosting \& } \\
\text { domain }\end{array}$ \\
\hline 9. Revenue Streams & $\begin{array}{l}\text { - Penjualan suku cadang } \\
\text { mobil \& aksesoris } \\
\text { - Pelayanan jasa service }\end{array}$ \\
\hline
\end{tabular}

\subsection{Activity Diagram}

Activity diagram merupakan gambaran sebuah alur dari aktifitas yang dilakukan oleh proses binsis. Berikut ini activity diagram yang penulis buat dalam penelitian ini:

a. Proses Pemesanan

Pada gambar 3 adalah penjelasan mengenai proses pemesanan dimana customer yang hendak memesan dapat memilih produk yang diinginkan melalui website Guna Motor Online dan setelah menemukan produk yang dinginkan, customer dapat memasukanya kekeranjang belanja terlebih dahulu. Customer bisa melihat total harga atau jumlah 
produk yang di pesan melalui keranjang belanja/ view cart dan menambah ataupun menghapus daftar belanja. Jika customer ingin melanjutkan pemesanan dengan memilih checkout diminta untuk login terlebih dahulu, customer sudah terdaftar hanya perlu login kembali, tapi jika customer belum terdaftar, customer harus melakukan pendaftaran terlebih dahulu.

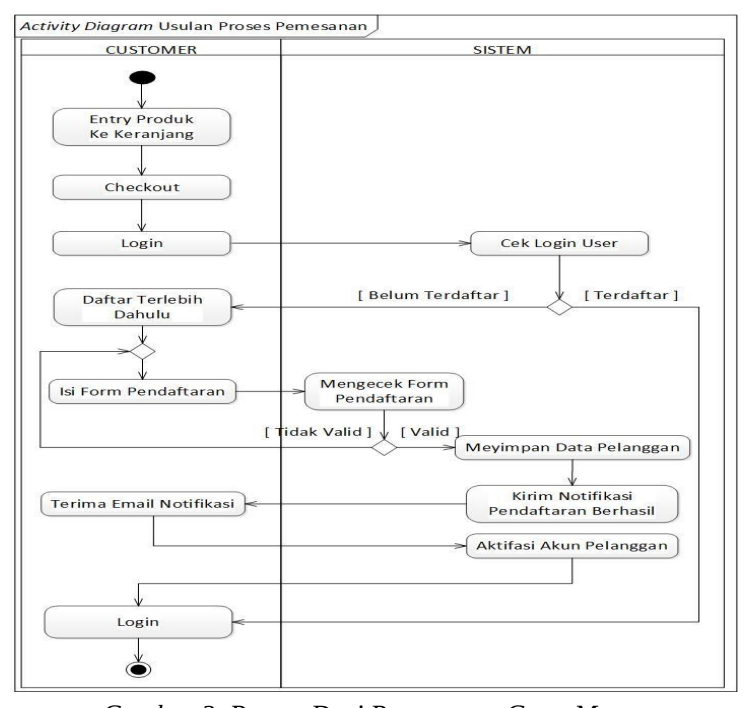

Gambar 3. Proses Dari Pemesanan Guna Motor

b. Proses Pembayaran

Pada gambar 4 adalah penjelasan mengenai proses pemesanan dimana Setelah berhasil login customer diminta untuk memasukan alamat pengiriman lengkap, memilih jasa kurir untuk pengiriman produk dan metode pembayaran yang ingin dipakai. Customer akan mendapakan email notifikasi nota bukti pemesanan. Customer yang sudah menerima email notifikasi nota bukti pemesanan yang dikirim oleh sistem dapat melakukan pembayaran sesuai jumlah nota pemesanan.

Setelah melakukan pembayaran maka customer harus konfirmasi pembayaran terlebih dahulu dengan memilih menu konfirmasi pembayaran lalu mengupload bukti pembayaran, sistem akan menyimpan data dan memberikan notifikasi kepada admin. Selanjutnya admin akan mengecek konfirmasi pembayaran apakah sudah sesuai atau belum, jika belum admin akan mengkonfirmasi ke customer dan diharapkan melakukan konfirmasi ulang, jika sesuai maka admin akan merubah status pembayaran.

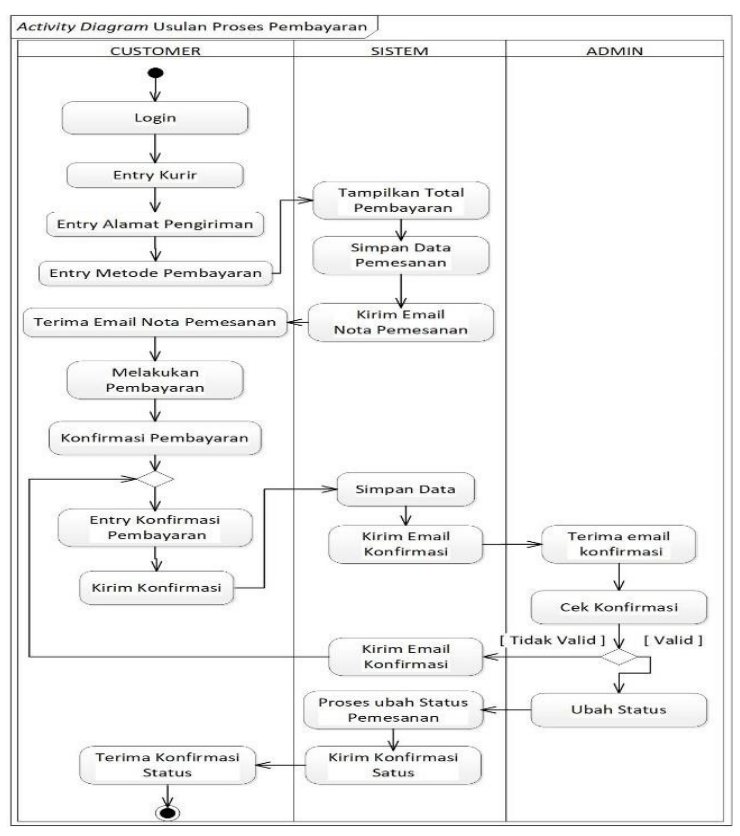

Gambar 4. Proses Dari Pembayaran Guna Motor

\subsection{Class Diagram}

Class Diagram untuk membantu dalam memvisualisasikan struktur kelas dari suatu system dan hubungan antara kelas. Berikut gambar 5 merupakan penjelelasan class diagram Guna Motor:

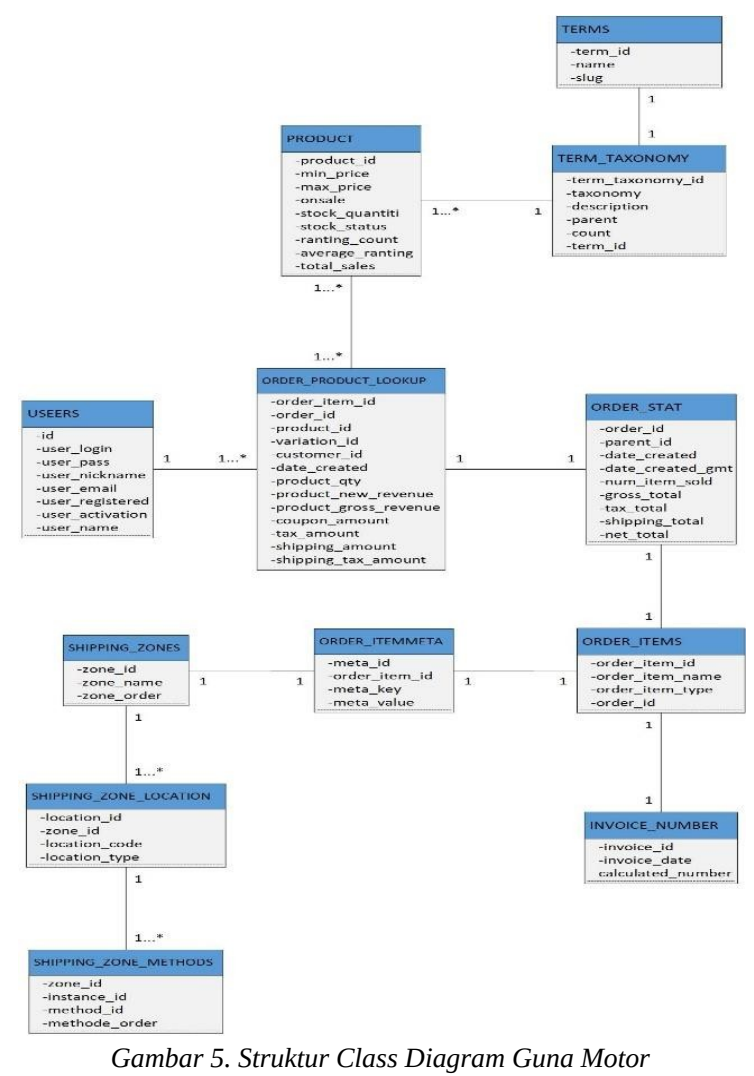




\subsection{Use Case Diagram}

Use Case Diagram untuk mengambarkan interaksi antar actor dan use case dengan tujuan mengenali interaksi mereka dalam suatu sistem[4]. Berikut proses bisnis usulan yang dibuat sebagai berikut:

\section{a. Use Case Diagram Master}

Pada gambar 6 merupakan penejalasan dari use case diagram master actor admin dan customer. Dimana terdapat entry product, entry kategori, entry data kurir, entry data customer dan sistem menjalankan email aktifasi pendaftaran.

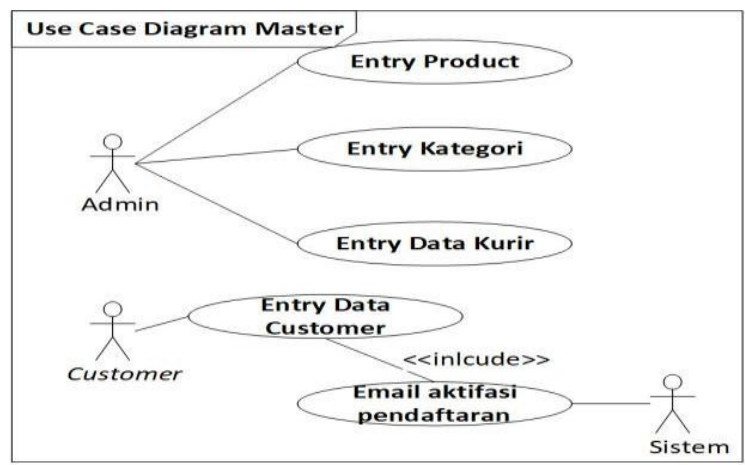

Gambar 6. Penjelasan Use Case Diagram Master

b. Use Case Diagram Transaksi

Pada gambar 7 merupakan penjelasan dari use case diagram transaksi terdiri dari actor customer dan admin. Dimana actor customer terdiri dari entry pemesanan, entry bukti pembayaran, entry penerimaan produk, dan actor admin terdiri dari entry resi pengiriman, cetak faktur pemesanan.

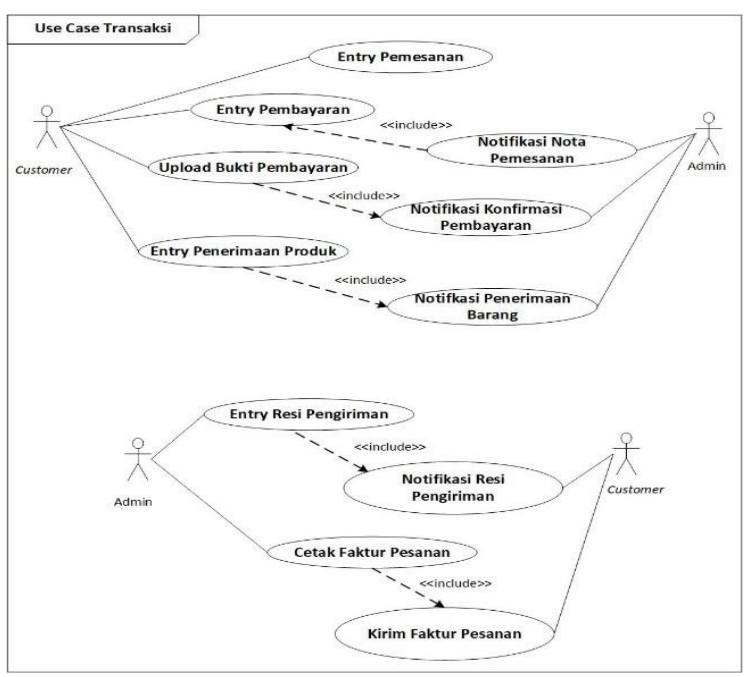

Gambar 7. Penjelasan Use Case Doagram Transaksi

c. Use Case Diagram Laporan

Pada gambar 8 merupakan penjelasan dari use case diagram laporan dengan actor admin dan pemilik Guna Motor. Dimana actor admin terdiri dari cetak laporan penjualan, cetak laporan pembayaran, cetak laporan pengiriman, cetak laporan stok, cetak laporan rekapitulasi.

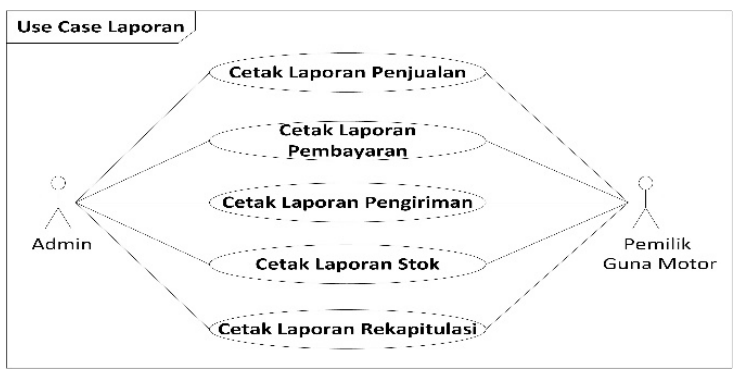

Gambar 8. Penjelasan Use Case Laporan

\subsection{Interaction Flow Medeling Languange}

Interaction Flow Modeling Language (IFML) adalah bahasa pemodelan untuk front-end pada perangkat lunak yang terinspirasi dari webml yang digunakan untuk mengekspresikan konten, interaksi penguna, dan mengatur perilaku pada front-end dari sebuah perangkat lunak[5]. Berikut adalah penjelasan IFML ada yang di Guna Motor :

a. IFML Entry Pemesanan

Pada gambar 9 penjelasan mengenai ifml entry pemesanan dapat dilihat setiap customer melakukan pemesanan dimenu shop dan menambah produk yang ingin dibeli akan muncul di cart belanja kemudian sistem akan menampilkan detail dari produk yang dipilih oleh customer, pada cart belanja customer dapat menambah atau menghapus produk yang tadi telah dipilih .

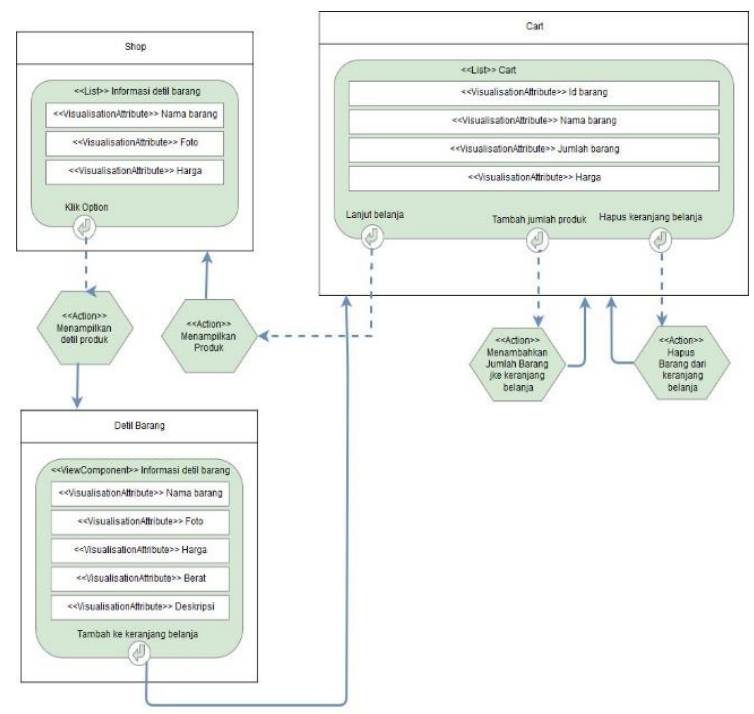

Gambar 9. Penjelelasan IFML Entry Pemesanan

b. IFML Entry Pembayaran

Pada gambar 10 merupakan penjelasan dari IFML Entry pembayaran sebagai berikut. Customer 
yang ingin malakukan pembayaran akan memilih membuka cart dan memilih menu checkout, sistem akan menampilkan detil pembayaran yang harus dilakukan oleh customer, setelah melengkapi data checkout sistem akan mengirim receifed atau konfirmasi pembayaran.

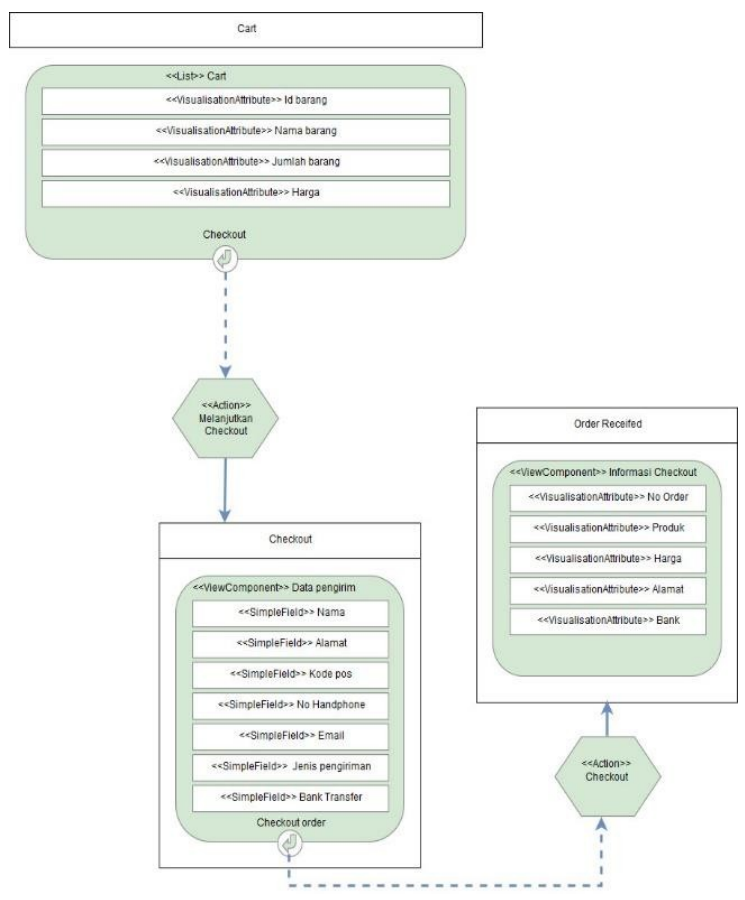

Gambar 10. Penjelasan IFML Entry Pembayaran

\subsection{Sytem Sequance Diagram (SSD)}

Berikut adalah System Sequence diagram (SSD) yang digunakan oleh penulis :

a. (SSD) Entry Pemesanan

pada gambar 11 adalah penjelasan system diagram entry pemesanan dimana cutomer membuka menu shop dan system menujukan tampilan data produk kemudian customer memilih produk yang diinginkan, terdapat loop dimana customer bisa berulang kali memilih produk untuk diamsukan ke cart . Setelah memilih customer membuka cart untuk melihat produk apa yang sudah diambil dan terdapat loop jika ingin melakukan penamban dan penghapusan secara berulang.

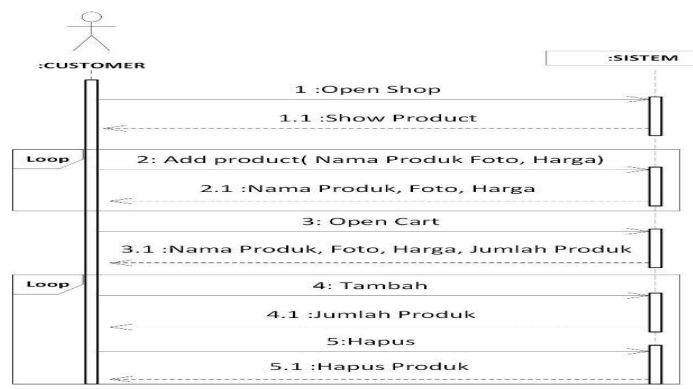

Gambar 11. Penjelasan SSD Entry Pemesanan b. (SSD) Entry Pembayaran

Pada gambar 12 adalah penjelasan system diagram entry pembayaran dimana customer membuka menu cart system menampilan detil produk yang dipilih, kemudian customer membuka menu checkout untuk melakukan pembayaran dan system menampilkan menu checkout. Setelah itu customer mengentry data alamat, jenis pengiriman dan metode pembayaran kemudian customer menyimpan dengan memilih place order dan system menyimpan data pembayaran serta mengirim notifikasi pemesanan.

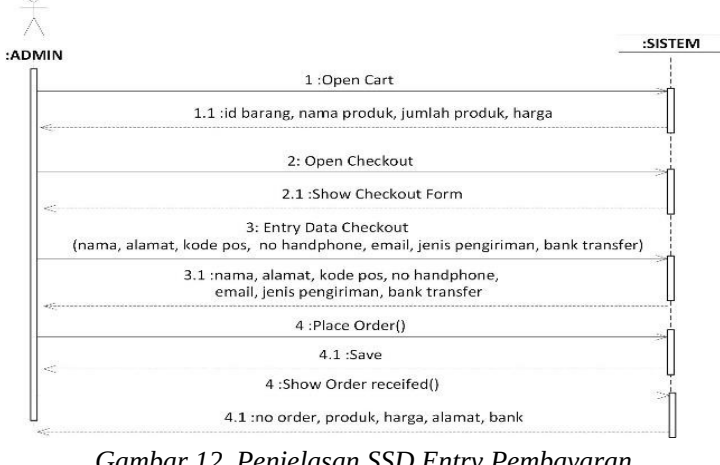

\subsection{Implementasi Sistem}

a. Tampilan Depan Pada Gunamotoronline Berikut gambar 13 adalah tampilan depan website gunamotoronline

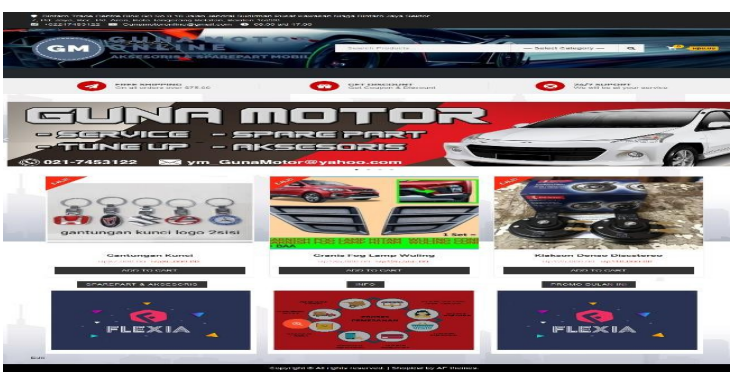

Gambar 13. Tampilan Depan Website Gunamotoronline

b. Tampilan Shop Pada Gunamtoronline Berikut gambar 14 adalah tampilan shop website gunamotoronline.

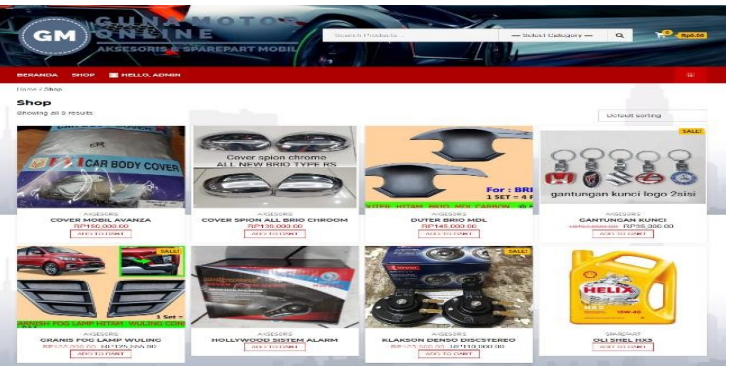

Gambar 14. Tampilan Shop Website Gunamotoronline 
c. Tampilan Cart Pada Gunamotoronline

Berikut gambar 15 adalah tampilan cart website gunamotoronline.

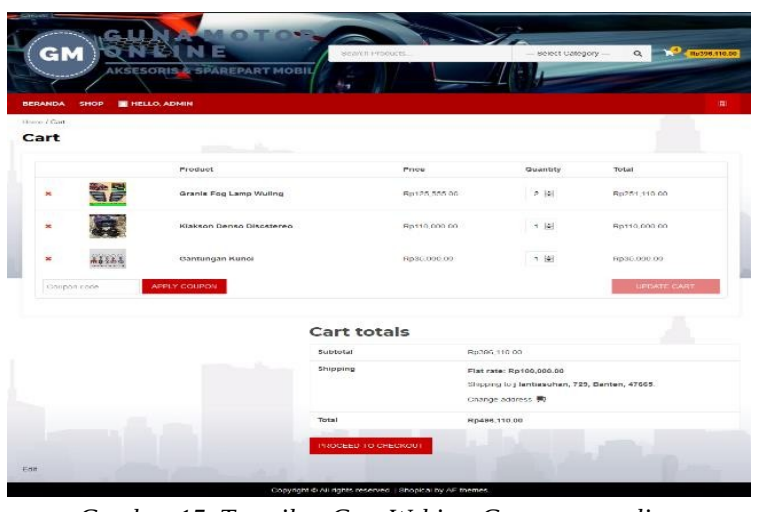

Gambar 15. Tampilan Cart Webiste Gunamotoronline

d. Tampilan Checkout Pada Gunamotoronline Berikut Gambar 16 adalah tapilan checkout website gunamotoronline

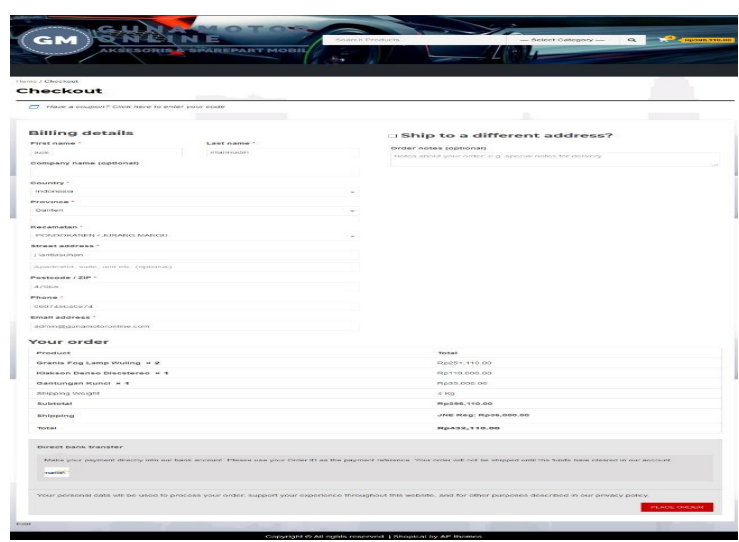

Gambar 16. Tampilan Checkout Website Gunamotoronline

e. Tampilan Laporan Penjualan Gunamotoronline Berikut gambar 17 adalah tampilan laporan penjualan gunamotoronline
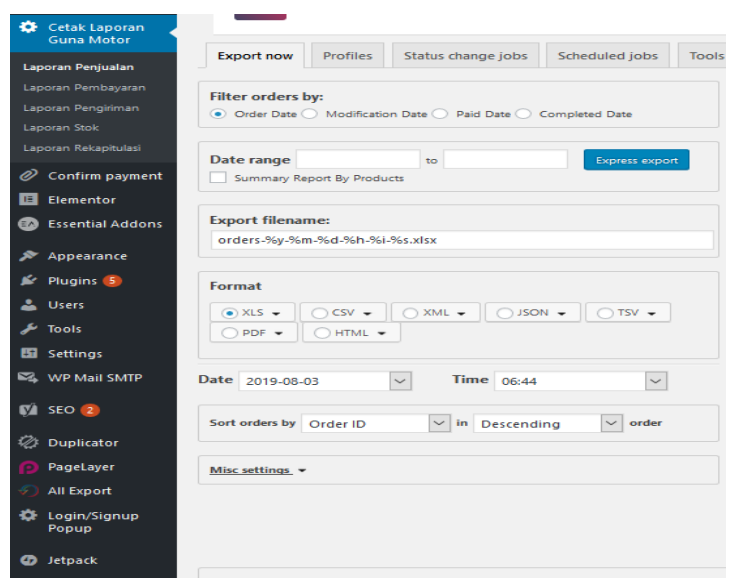

Gambar 17. Tampilan Laporan Penjualan Website Gunamotoronline

\subsection{Hasil Keluaran Program}

Adapun hasil dari keluaran program pada Guna Motor diantaranya :

a. Notifikasi Pemesanan

Berikut hasil notifikasi pemesanan yang dijelaskan pada gambar 18

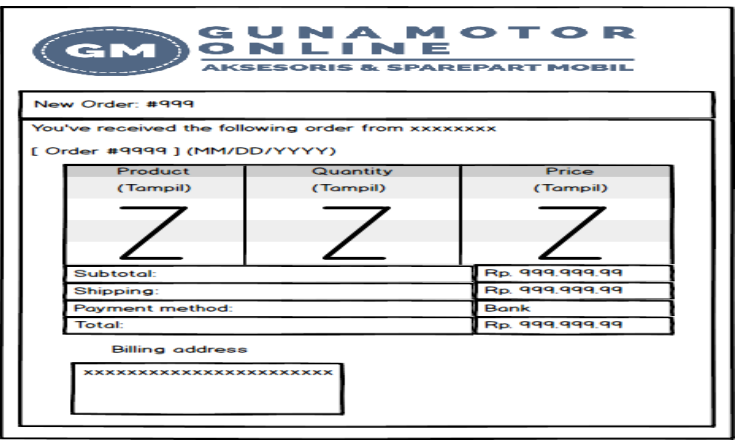

Gambar 18. Notifikasi Pemesanan

b. Laporan Penjualan

Berikut hasil keluaran laporan penjualan yang dijelaskan pada gambar 19

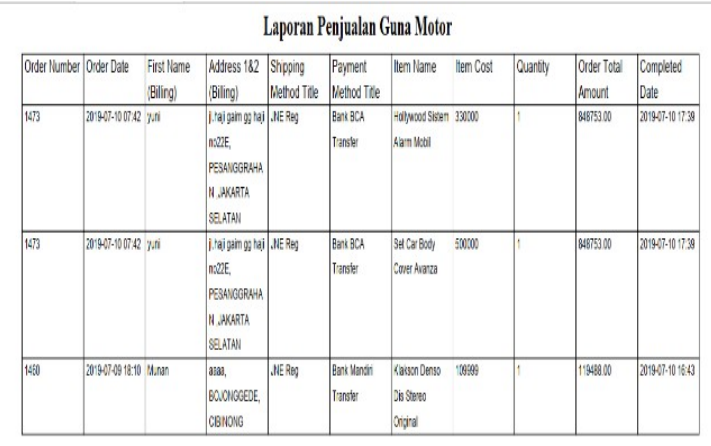

Gambar 19. Keluaran Laporan Penjualan

\subsection{Implementasi Strategi Search Engine Optimization (SEO)}

Berikut teknik SEO yang di lakukan pada website gunamotoronline.

a. Menggunakan Plugin Yoast SEO

1. Install plugin Yoast SEO

2. Setelah install masuk ke dashboard dengan memilih general

3. Pilih features disebelah kanan dashboard

4. Lalu mulai dengan membuat on semua fitur yang tersedia di Yoast Seo

5. Setelah itu setting Yoast Seo di produk

6. membuat on semua fitur lalu memilih

7. webmaster tool yang disebelah kanannya

8. Kemudian pilih google verification code untuk menyambungkan ke google search console

b. Tambah Link Pencarian di google search console. 
1. Daftar google search console dan tambah domain ke search console yang ada di webmaster tool Yoast Seo yang ada disebelah kanan.

2. Upload file verifisikasi

3. Copy kode yang disediakan lalu paste ke dalam template yang digunakan.

4. Paste ke menu verifikasi google search console di plugin yoast seo dan pilih verfy.

5. Setelah nya klik menu sitemaps dan masukan bagian akhir dari url sitemaps website kedalam kolom add new sitemap dan submit.

6. Buka search google cari serach.google.console.com

7. Setelah masuk tambahkan property berupa link produk yang akan seo kan.

c. Hasil Dari Teknik Search Engine Optimization (SEO)

Gambar 20 merupakan penjelasan tentang hasil teknik seo yang dilakukan.

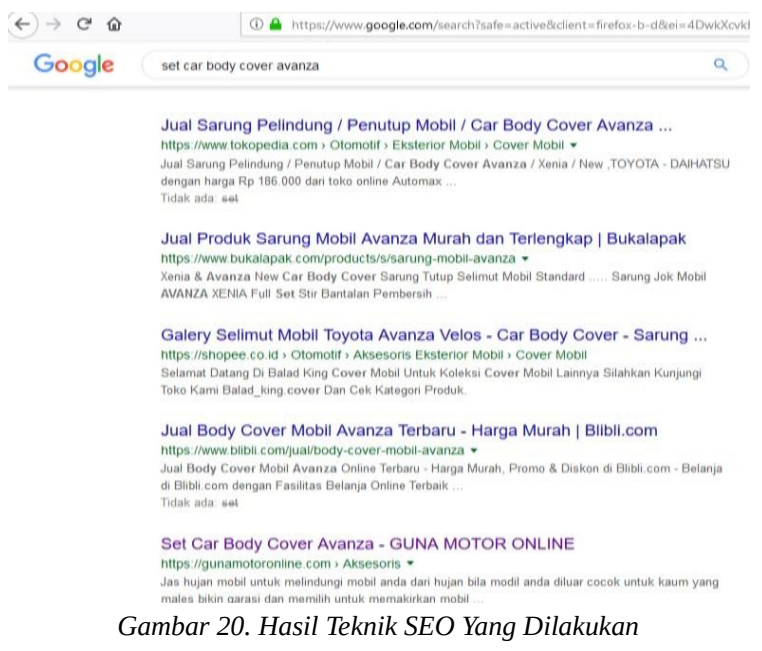

\section{KESIMPULAN}

E-commerce merupakan sarana bisnis yang menguntungkan untuk menaikan saranya penjualan sehingga menjadikanya peluang bisnis yang digemari saat ini. Dalam implementasi sistem penjualan $e$ - commerce pada Guna Motor terdapat beberapa kesimpulan:

a. Dengan adanya sistem penjualan online (ecommerce) maka Guna Motor dapat mempermudah proses transaksi yang selama ini sifatnya konvensional menjadi lebih modern dengan tersedianya transaksi online dan data atau dokumen yang ada dapat dikelola dengan efektif.

b. Dengan adanya laporan stok barang admin dapat lebih mudah mengetahui jumlah stok yang tersedia pada saat customer melakukan pemesanan

c. Dengan sistem penjualan online maka tempat penyimpanan data secara otomatis tersimpan di database sistem tanpa takut kehilangan data lagi dan pembuatan laporan menjadi lebih mudah.

d. Dengan adanya fitur promosi melalui Instagram yang ada Guna Motor dapat memperluas pemasaran konsumen menjadi lebih mudah mendapatkan informasi tentang produk tanpa harus datang langsung ke Guna Motor.

\section{DAFTAR PUSTAKA}

[1] Rerung, Rintho Rante., 2018, E-Commerce Menciptakan Daya Saling Melalui Teknologi Informasi, Yogyakarta, CV Budi Utama, pp 20- 23.

[2] Rohi, Abdulloh., 2016, Trik Mudah Membuat CMS Website dari Nol, Jakarta, Elex Media Komputindo.

[3] Hamdani, Agus Umar dan Mubarak, Rakha Luri., 2019, Seminar Nasional Multidisiplin Ilmu dan Call For Papers UNIBANK (SEND_U) Ke-5 Tahun 2019, ISBN: 978-979-3649-99-3, Universitas STIKUBANK: Semarang,

[4] Yasn, Verdi., 2012, Rekayasa Perangkat Beriorientasi Objek, Jakarta, Mitra Wacana Media.

[5] Suryanto, S., Pattiasina, J. dan Soetarmono, A., 2017, Perancangan dan Pengembangan Toko Online dengan Metode Interaction Flow Modeling Language (Studi Kasus Toko Winata, Jurnal TEKNIKA, 6(1), pp 7-18. 